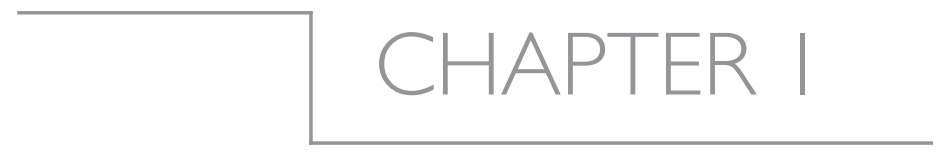

\title{
The Prince EdWARd IsLANDS IN A GLOBAL CONTEXT
}

\section{Steven L. Chown and P. William Froneman}

The history of the planet is one of change. Continental positions have moved, sea-levels have advanced and retreated, mountains have been formed and eroded, climates have varied from warm to cool and back again, and life has responded to and sometimes driven these processes, with species and higher taxa waxing and waning for the last several billion years (Stanley 1989; Behrensmeyer et al. 1992). More recently, humans have come to influence these changes. Our recent history has been one of significant effects on the abiotic environment, including elevation of atmospheric greenhouse gas concentrations, depletion of stratospheric ozone, and alterations to the global climate (Watson 2002; Domack et al. 2005). In turn, changing climates have had and continue to have profound effects on biodiversity, ranging from population and species loss (Pounds et al. 2006) to alterations in species distributions, changes in phenology, and shifts in ecological regimes (Walther et al. 2002; Parmesan \& Yohe 2003; Root et al. 2003).

Humans have also had profound direct effects on landscapes, populations and species. Habitat destruction and transformation have been responsible for considerable biodiversity loss, with co-extinctions exacerbating the scale of the problem (e.g. Beier et al. 2002; Brooks et al. 2002; Koh et al. 2004; Dunn 2005; Millennium Ecosystem Assessment 2005). Likewise, direct and indirect

\footnotetext{
S.L. Chown \& P.W. Froneman (eds.) The Prince Edward Islands $\bullet$ Land-Sea Interactions in a Changing Ecosystem, 1-16
} 
utilization has meant that many species are critically endangered (Baum et al. 2003; Brashares et al. 2004; Pauly et al. 2005). As a consequence of human activities such as trade and shipping, the movement of species from their indigenous ranges to areas where they have previously not occurred, is also having significant effects on global biodiversity (Mack et al. 2000; Bax et al. 2001; Grosholz 2002; Blackburn et al. 2004; Drake \& Lodge 2004; Richardson \& Van Wilgen 2004; Cassey et al. 2005). The interactive effects of invaders can lead to wholesale ecosystems changes, termed invasional meltdown (O'Dowd et al. 2003; Sanders et al. 2003; Grosholz 2005), and the extent and pace of invasion globally (e.g. Gaston et al. 2003) has led many to suggest that the next period in the earth's history might be one of substantial biotic homogenization (McKinney \& Lockwood 1999; Olden et al. 2004).

In many instances, the effects of habitat destruction and alteration, climate change, and biological invasions are likely to be interactive. For example, nutrient loading and disturbance often promote biological invasions, increasing the chances for the progress of non-indigenous species from establishment to full invasion (e.g. Dukes \& Mooney 1999; Huston 2004). Habitat availability and fragmentation also substantially alter the extent and nature of the response of species to changing climates (Hill et al. 1999, 2006). At least in some instances, changing climates might favour introduced over indigenous species as a consequence of substantial differences in the life history and physiological traits of the two sets of organisms (Stachowicz et al. 2002; Walther et al. 2002; Daehler 2003; Chown et al. 2007). In consequence, an understanding of human impacts on the environment must not only involve investigations of direct effects of major processes, such as climate change and habitat transformation, but also their interactive effects (Dukes \& Mooney 1999). Indeed, in describing the effects of interactions between global change (of all kinds) and biological invasions, Mooney and Hobbs (2000) have noted that such interactions are becoming an ever more important feature of the world, substantially affecting our capacity to retain biodiversity and the services we derive from it.

\section{I.I Environmental change in the Antarctic region}

Antarctica, its surrounding islands, and the Southern Ocean have changed in concert with global changes, and geological and oceanographic evolution in the region has precipitated large-scale alterations of the global climate (see summaries in Crame 1997; Clarke 2003; Peck et al. 2006; Chown \& Convey 2007). However, in many ways the region has long been considered comparatively isolated from the rest of the planet. The Southern Ocean is recognized as a particularly well-defined marine ecosystem, especially given that the Antarctic Circumpolar Current has been in evidence for c. 25 million years, endemism of many marine groups is substantial (Longhurst 1998; Clarke \& Johnston 2003; Clarke et al. 2005), and in several terrestrial taxa endemism is significant too (Chown \& Convey 2007). Likewise, and despite their varied histories (LeMasurier \& Thompson 1990; Hall 2002), many of the Southern 
Ocean islands are well removed from major landmasses, and show substantial endemism in a range of groups (Gressitt 1970; Chown et al. 1998; Greve et al. 2005). In terms of direct human influence, the first landing on Antarctica took place only in 1821. Many of the Southern Ocean islands have had similarly short human histories (Headland 1989; Chown et al. 2005), and permanent human settlements in the region have remained rare.

This perception of isolation is nonetheless deceptive. Climatic teleconnections between the Antarctic and elsewhere are well-established (Bender et al. 1994; Carleton 2003), and many regions, such as the Antarctic Peninsula and several sub-Antarctic islands, are showing evidence of pronounced climate change in step with global events. For example, temperatures have increased by several degrees over the past half century at some sites along the Antarctic Peninsula (King \& Harangozo 1998), and rain is falling there for the first time in recorded history. In the sub-Antarctic, temperature increases over similar periods have been lower, but still substantial, whilst precipitation has declined by as much as $600 \mathrm{~mm}$ per annum (Bergstrom \& Chown 1999). Likewise, despite the late arrival of humans in the region, their impacts on vertebrate populations escalated rapidly, leading to widespread declines in several species (many of which have now recovered) and likely irreversible regime shifts (Laws 1984; Weimerskirch et al. 2003). Whilst resource depletion has shifted away from seals, whales and seabirds, fish continue to bear the brunt of exploitation (Brandão et al. 2002). More recently, scientific research and its logistic support in the Antarctic, and tourism to a more limited number of sites have increased dramatically (Naveen et al. 2001; Frenot et al. 2005). In consequence, a wide range of species has been introduced from elsewhere, often having significant impacts on local populations and ecosystem functioning (Frenot et al. 2005). Moreover, interactions between climate change and alien species are expected to exacerbate the impacts of these species, and to facilitate additional humanmediated colonization events and invasions (Kennedy 1995; Bergstrom \& Chown 1999; Chown \& Convey 2007).

Therefore, the Antarctic and Southern Ocean regions are in many ways a microcosm of the situation found elsewhere on the planet. Significant changes in many systems have taken place rapidly (Bergstrom \& Chown 1999; Weimerskirch et al. 2003; Barnes et al. 2006), and major concerns about the conservation of the region and its biodiversity have been raised (e.g. Dingwall 1987, 1995). Nonetheless, the region also differs from others in ways that offer advantages for understanding interactive effects of major environmental changes, their conservation implications, and the ways in which they might be addressed. For example, in terrestrial systems the direct impacts of humans (e.g. habitat destruction as a consequence of agriculture) are less pronounced in the Antarctic than elsewhere, and, because the region is more isolated than many others, immigration can be reasonably well documented and the source of propagules identified (e.g. Crafford \& Chown 1987; Marshall \& Chalmers 1997; Greenslade et al. 1999; Muñoz et al. 2004). Thus, the effects 
on biodiversity of rapidly changing climates and biological invasions can be readily comprehended because of the absence of many factors that confound investigations elsewhere (Bergstrom \& Chown 1999; Chown et al. 2005). Moreover, it has long been appreciated in the region that an understanding of the ecology of coastal, offshore and island ecosystems, and comprehension and prediction of the effects of environmental change on these systems, cannot be achieved without considering interactions between the marine and terrestrial environments (see Smith 1977; Smith \& Steenkamp 1990; Pakhomov \& Chown 2003). In consequence, research that has been done in the region not only provides a useful perspective on Antarctic biodiversity and ecosystem functioning (Knox 1994; Peck et al. 2006), but also provides broader insights into the patterns in and processes underlying biodiversity more generally, and how this diversity will respond to environmental change (Chown et al. 2000; Clarke 2003). In this regard, the Prince Edward Islands are a model system.

\section{I.2 The Prince Edward Islands}

Marion Island and Prince Edward Island form the Prince Edward Islands. Together with a small number of other islands and archipelagos, such as South Georgia, Bouvetøya, Crozet, Kerguelen, Heard, Auckland and Campbell, they represent the only land in the vast Southern Ocean, which occupies half of the area between $30^{\circ}$ and $60^{\circ}$ South (as opposed to the $7 \%$ of area that ocean occupies in the same northern latitudes) (Chown et al. 2004). The nearest landfall to both of the islands is Ile aux Cochons of the French Crozet Island Group, which lies $950 \mathrm{~km}$ to the east. The two islands lie close to each other, with the more southerly and larger island, Marion $\left(46^{\circ} 54^{\prime} \mathrm{S}, 37^{\circ} 45^{\prime} \mathrm{E}\right)$, separated from the smaller Prince Edward Island $\left(46^{\circ} 38^{\prime} \mathrm{S}, 37^{\circ} 57^{\prime} \mathrm{E}\right)$ by $19 \mathrm{~km}$.

The islands are young in geological terms. The oldest recorded date for lavas on Marion Island is 450000 years, and it seems likely that the islands are less than one million years old (McDougall et al. 2001). Local climates and the extent of glaciation have varied substantially since the islands became sub aerial (McDougall et al. 2001; Hall 2002), in keeping with global climatic fluctuations (Augustin et al. 2004). It seems likely that Marion Island was subjected to at least five, though possibly more, glaciations during the Quaternary, whereas there is no evidence for glaciation on Prince Edward Island. The glacial cycles on Marion Island had a major effect on the vegetation. Glacial maxima generally caused the local extirpation of vascular plants, with the possible exception of species such as the cushion-forming Azorella selago (Scott 1985). During the more recent interglacials the vegetation resembled that currently found on the island, although in some cases it included species, such as the brassica Cardamine, that are not present in the modern flora (Scott \& Hall 1983). The glacial cycles are also thought to have had a substantial influence on the invertebrate fauna, reflected in low habitat specificity and species richness in the vegetated biotope, but much higher richness and greater habitat specificity 
in the epilithic biotope (rock faces, fellfield, polar desert) (Chown 1989, 1990; Barendse et al. 2002). This pattern seems to be repeated across most of the sub-Antarctic islands and in Antarctica (Chown 1994; Chown \& Klok 2001; Marshall \& Convey 2004).

More recent changes have included historical decimation of seal populations (Cooper \& Headland 1991) and modern over-exploitation of marine resources (specifically the Patagonian toothfish, Dissostichus eleginoides) (Brandão et al. 2002). The latter has had substantial indirect impacts on several seabird species as a consequence of long-line fishing-associated mortality (Nel \& Nel 1999; Nel et al. 2000). Climates have also been changing rapidly at the islands. Sea surface temperatures and Stevenson Screen temperatures have increased by more than $1^{\circ} \mathrm{C}$ over the past 50 years, and on land mean annual precipitation has declined by $\approx 600 \mathrm{~mm}$ (Smith 2002; Mélice et al. 2003; le Roux \& McGeoch 2007). These changes in climate have had or seem set to have major impacts on assemblage structure and ecosystem functioning in both marine and terrestrial environments (Smith \& Steenkamp 1990; Chown \& Smith 1993; Smith 2002; Pakhomov \& Chown 2003).

Many of the impacts of climate change are being mediated through interactions between indigenous and invasive species (Chown \& Smith 1993; Frenot et al. 2005). Since the discovery of the islands and their exploitation by sealers, but particularly since their annexation by South Africa in 1947 and the establishment of a scientific station, a steady stream of non-indigenous species has colonized the island (Watkins \& Cooper 1986; Cooper \& Condy 1988; Chown et al. 2002). Some of them have become highly invasive, and have caused local extinctions and/or major changes to the local ecosystem. Amongst the most damaging invaders have been feral cats (now extirpated) (Bester et al. 2002), house mice (Crafford 1990; Chown \& Smith 1993), the grass Agrostis stolonifera, and the forb Sagina procumbens (Gremmen et al. 1998; Gremmen \& Smith 1999). Some evidence now exists that house mice are starting to attack procellariiform chicks (including those of albatrosses), as is the case on Gough Island (Jones et al. 2003; Cuthbert \& Hilton 2004). What the effects are of other alien species, such as aphids, mosses and isopods (Crafford et al. 1986; Slabber \& Chown 2002) is not known, nor is the extent of marine invasions. Hull fouling is known to be a significant concern elsewhere in the region (Lewis et al. 2003, 2006), and recent studies have recorded both hull fouling and invasive alien species in the sea chests of the research and supply vessel, the SA Agulhas (Lee \& Chown 2007).

Thus, just like other areas in the region, the Prince Edward Islands have been subject to considerable past geological and climatological variability, are experiencing rapid modern changes owing to climate change and biological invasions, and have been at the receiving end of historical resource exploitation and continue to experience it today. However, unlike many other areas, a considerable body of scientific research has been undertaken to understand these changes and how they have affected interactions between marine and 
terrestrial systems of the islands, and to determine and demonstrate, what lessons they hold for other areas of the planet.

\section{I.3 Research at the Prince Edward Islands}

\section{I.3.I Early terrestrial work}

Although the Prince Edward Islands were probably discovered in the mid 1600 s, it was not until the early 1800s that the first landing was effected. By the early 1900s most of the fur seals and elephant seals on the two islands had been exterminated (Cooper \& Headland 1991). The early history of the islands was thus one of considerable exploitation, as was the case for most other Southern Ocean islands (Headland 1989; Downes 2002). Although a variety of scientific expeditions visited the Prince Edward Islands from the late 1800s onwards (Cooper \& Headland 1991), it was only in 1965/66 that the first formal geological and biological research was conducted. This resulted in a substantial volume providing comprehensive baseline information on the climatology, geology, glacial and vegetation histories, and biodiversity of the islands (Van Zinderen Bakker et al. 1971). It also set the stage for a large and comprehensive terrestrial research programme.

In essence, the programme addressed four major sets of goals from the early 1970s through to the end of the century, and can therefore be divided into four phases, named by Smith (1991): the reconnaissance, whole island systems, national priorities, and climate change phases. The reconnaissance phase was just that, focussing largely, but not exclusively, on cataloguing the biota. In the next phase, the emphasis switched to understanding the whole island ecosystem, a goal that was influenced to a large degree by the contemporaneous International Biological Programme's Biome Project. This work also involved detailed investigations of nutrient inputs by vertebrates to the terrestrial environment, so forming the first investigations of land-sea interactions. The whole systems approach continued to dominate in the national priorities phase, but by then research also came to include a variety of topics that did not directly address the whole systems model, but were concerned with national significance or especially suited to the opportunities provided by the island system and its biota. Investigations of the impacts of alien species, especially feral cats and house mice had already been established as important avenues of conservation research (Bester \& Skinner 1991; Smith 1991). The late 1980s and early 1990s saw a switch in emphasis to studies of the impacts of climate change on the islands. Shortly thereafter a change in administration of research of the islands led to a focus on conservation and monitoring issues identified by the Prince Edward Islands Management Plan (Anonymous 1996), precipitated largely by the declaration of the islands as Special Nature Reserves in 1995. Whilst some other work took place, the emphasis of terrestrial studies was largely on conservation-related science. 
Much of this research was essentially land-based, even though large projects were concerned with marine vertebrate predators and their diets. What these predators were doing at sea was more poorly known, mostly as a consequence of an early, negligible oceanographic capacity, and a later oceanographic focus on other significant questions and regions of the Southern Ocean (Lutjeharms 1991). Although much work was done on the nearshore and intertidal zones (see de Villiers 1976; Beckley \& Branch 1992), only a single programme (the Marion Offshore Ecosystem Study) focussed on deeper waters.

\subsubsection{Marine investigations}

The study of the marine environment in the vicinity of the Prince Edward Islands can be traced to the late nineteen century when the HMS Challenger briefly visited the islands in 1873. Nearly a hundred years later (1976), the first comprehensive investigation of the biology of the marine environment was undertaken when the MS Marion Dufresne visited the islands (Grindley \& Lane 1979; Pakhomov \& Froneman 1999a; McQuaid \& Froneman 2004). This study provided the first scientific information on plankton community structure and distribution within the vicinity of the Prince Edward Islands (Grindley \& Lane 1979).

The systematic study of the link between the marine and terrestrial environment only began in the late 1980s. The Marion Offshore Ecosystem Study (MOES) addressed the problem of how the Prince Edward Islands, located within the relatively unproductive Polar Frontal Zone waters (PFZ), could seasonally sustain enormous numbers of top predators including seals, penguins and flying seabirds. The initial target of investigation was the existence of an island mass effect at the archipelago, a phenomenon of greatly enhanced primary production in a low productivity part of the ocean, and how, or whether this production fed through to the top predators (Boden 1983; Allanson et al. 1985; Pakhomov \& Froneman 1999a). The programme was unique in that it placed equal emphasis on the availability of food and the importance of its physical supply to consumers. By the end of the programme an understanding of trophic relationships between autochthonous or allochthonous food sources and the top predators was developed as what became known as the "life support system" of the islands (Pakhomov \& Froneman 1999a; Pakhomov \& Chown 2003; McQuaid \& Froneman 2004).

The subsequent research programmes conducted in the 1990s and early 21 st century, the Marion Islands Offshore Variability Study (MIOS), the Marion Offshore Variability Study (MOVES) and Dynamics of Eddies Impact on Marion's Ecosystem (DEIMEC), modified or refined the concept of the "life support system of the islands" (Pakhomov \& Froneman 1999b; Pakhomov \& Chown 2003; McQuaid \& Froneman 2004). These investigations have focused on the upstream region (west) of the islands. The main finding thereof was that plankton distribution and species composition was closely linked to mesoscale variability in the oceanographic environment, including meanders in fronts 
that delimit the Polar Frontal Zone and the presence of both warm and cold core features. More significantly, these studies highlighted the importance of the interaction of the Antarctic Circumpolar Current (ACG) with prominent topographic features, and its effects on zooplankton community composition and the delivery of food to pelagic predators on the islands (Pakhomov \& Froneman 1999a; Pakhomov \& Chown 2003; McQuaid \& Froneman 2004).

\subsubsection{Recent developments}

Over the last decade, research at the islands has focussed mostly on the terrestrial system, although considerable advances were made in understanding marine processes around the islands. Unfortunately, the marine research has been restricted to the autumn months, and investigations of seabirds and seals have been land-based, with limited work on at-sea distributions. Despite proposals for detailed work on understanding the marine system and the resource base it provides, especially during the months when the majority of seabirds and seals reproduce, such work was much delayed (Cooper \& Ryan 2001), or scaleddown (Nel et al. 2001), and has only recently become the focus of attention. Therefore, whilst understanding of the terrestrial system and its inhabitants is becoming ever more sophisticated, insights into the surrounding marine systems and the ways in which they influence terrestrial processes has lagged behind. One of the major consequences of the limited marine work is that the development of a major Marine Protected Area for the islands has had to be based largely on surrogate environmental information, rather than spatially comprehensive biological data (Lombard et al. 2007).

In the mid 2000s, another administrative change saw the research component of the South African National Antarctic Programme transferred from the Department of Environmental Affairs and Tourism to the relatively new Department of Science and Technology, with management thereof being undertaken by the National Research Foundation. A new science policy for the region (the Antarctic Research Strategy for South Africa) was articulated, with major themes including, inter alia, climatic variability and the responses of biodiversity to earth system variability. Since then, research has largely been required to address these goals and those of various international polar programmes, such as the International Polar Year. At the Prince Edward Islands, several new projects have started to build on the past work, including joint marine and terrestrial work on seabirds and seals and their foraging areas, investigations of microbial diversity using molecular techniques, and studies of the interactions between biodiversity and geomorphological processes.

\section{I.4 This book}

The period from the mid 1960s to the present has been an exceptionally productive one scientifically (Hänel \& Chown 1999). Substantial knowledge of the geology and biodiversity of the islands now exists, much is known about how the marine and terrestrial systems of the islands function, and comprehension 
of the nature of the interactions between the marine and terrestrial systems is well advanced. However, not since the landmark volume by Van Zinderen Bakker et al. (1971) has a review and synthesis of scientific knowledge of the islands and their biodiversity been presented. This book does just that in the context of the contribution this research has made to our understanding of environmental change in a system dominated by land-sea interactions.

\section{I.5 References}

Allanson, B.R., Boden, B.P., Paker, L. \& Duncombe Rae, C. 1985. A contribution to the oceanology of the Prince Edward Islands. In: Siegfied, W.R., Condy, P.R. \& Laws, R.M. (Eds.). Antarctic Nutrient Cycles and Food Webs. Springer, Berlin, pp 38-45.

Anonymous 1996. Prince Edward Islands Management Plan. Department of Environmental Affairs and Tourism, Pretoria.

Augustin, L., Barbante, C., Barnes, P.R.F., Barbola, J.M., Bigler, M., Castellano, E., et al. 2004. Eight glacial cycles from an Antarctic ice core. Nature 429, 623-628.

Barendse, J., Mercer, R.D., Marshall, D.J. \& Chown, S.L. 2002. Habitat specificity of mites on sub-Antarctic Marion Island. Environmental Entomology 31, 612-625.

Barnes, D.K.A., Hodgson, D.A., Convey, P., Allen, C.S. \& Clarke, A. 2006. Incursion and excursion of Antarctic biota: past, present and future. Global Ecology and Biogeography 15, 121-142.

Baum, J.K., Myers, R.A., Kehler, D.G., Worm, B., Harley, S.J. \& Doherty, P.A. 2003. Collapse and conservation of shark populations in the Northwest Atlantic. Science 299, 389-392.
Bax, N., Carlton, J.T., Mathews-Amos, A., Haedrich, R.L., Howarth, F.G., Purcell, J.E., et al. 2001. The control of biological invasions in the world's oceans. Conservation Biology 15, 1234-1246.

Beckley, L.E. \& Branch, G.M. 1992. A quantitative scuba-diving survey of the sublittoral macrobenthos at subantarctic Marion Island. Polar Biology 11, 553-563.

Behrensmeyer, A.K., Damuth, J.D., DiMichele, W.A., Potts, R., Sues, H.-D. \& Wing, S.L. 1992. Terrestrial Ecosystems Through Time. Evolutionary Paleoecology of Terrestrial Plants and Animals. University of Chicago Press, Chicago.

Beier, P., Van Drielen, M. \& Kankam, B.O. 2002. Avifaunal collapse in West African forest fragments. Conservation Biology 16, 1097-1111.

Bender, M., Sowers, T., Dickson, M.-L., Orchardo, J., Grootes, P., Mayewski, P.A. et al. 1994. Climate correlations between Greenland and Antarctica during the past 100,000 years. Nature 372, 663-666.

Bergstrom, D. \& Chown, S.L. 1999. Life at the front: history, ecology and change on Southern Ocean islands. Trends in Ecology and Evolution 14, 472-477. 
Bester, M.N., Bloomer, J.P., Van Aarde, R.J., Erasmus, B.H., Van Rensburg, P.J.J., Skinner, J.D., et al. 2002. A review of the successful eradication of feral cats from sub-Antarctic Marion Island, Southern Indian Ocean. South African fournal of Wildlife Research 32, 65-73.

Bester, M.N. \& Skinner, J.D. 1991. South African research on Antarctic seals. South African Fournal of Antarctic Research 21, 165-166.

Blackburn, T.M., Cassey, P., Duncan, R.P., Evans, K.L. \& Gaston, K.J. 2004. Avian extinction and mammalian introductions on oceanic islands. Science 305, 1955-1958.

Boden, B.P. 1983. Observations of the island mass effect in the Prince Edward archipelago. Polar Biology 5, 81-93.

Brandão, A., Watkins, B.P., Butterworth, D.S. \& Miller, D.G.M. 2002. A first attempt at an assessment of the Patagonian Toothfish (Dissostichus eleginoides) resource in the Prince Edward Islands EEZ. CCAMLR Science 9, 11-32.

Brashares, J.S., Arcese, P., Sam, M.K., Coppolillo, P.B., Sinclair, A.R.E. \& Balmford, A. 2004. Bushmeat hunting, wildlife declines, and fish supply in West Africa. Science 306, 1180-1183.

Brooks, T.M., Mittermeier, R.A., Mittermeier, C.G., da Fonseca, G.A.B., Rylands, A.B., Konstant, W.R., et al. 2002. Habitat loss and extinction in the hotspots of biodiversity. Conservation Biology 16, 909-923.

Carleton, A.M. 2003. Atmospheric teleconnections involving the Southern Ocean. Fournal of Geophysical Research Oceans 108, Art. No. 8080.
Cassey, P., Blackburn, T.M., Duncan, R.P. \& Chown, S.L. 2005.

Concerning invasive species: Reply to Brown and Sax. Austral Ecology 30, 475-480.

Chown, S.L. 1989. Habitat use and diet as biogeographic indicators for subantarctic Ectemnorhinini (Coleoptera: Curculionidae). Antarctic Science 1, 23-30.

Chown, S.L. 1990. Possible effects of Quaternary climatic change on the composition of insect communities of the South Indian Ocean Province Islands. South African Fournal of Science 86, 386-391.

Chown, S.L. 1994. Historical ecology of sub-Antarctic weevils (Coleoptera: Curculionidae): patterns and processes on isolated islands. Fournal of Natural History 28, 411-433.

Chown, S.L. \& Convey, P. 2007. Spatial and temporal variability across life's hierarchies in the terrestrial Antarctic. Philosophical Transactions of the Royal Society of London B 362, 2307-2331.

Chown, S.L., Gaston, K.J. \& Gremmen, N.J.M. 2000. Including the Antarctic: Insights for ecologists everywhere. In: Davison, W., Howard-Williams, C. \& Broady, P.A. (Eds.). Antartic Ecosystems: Models for Wider Ecological Understanding. New Zealand Natural Sciences, Christchurch, pp. 1-15.

Chown, S.L., Gremmen, N.J.M. \& Gaston, K.J. 1998. Ecological biogeography of southern ocean islands: Species-area relationships, human impacts, and conservation. American Naturalist 152, 562-575.

Chown, S.L., Hull, B. \& Gaston, K.J. 2005. Human impacts, energy availability, and invasion across Southern Ocean Islands. Global Ecology and Biogeography 14, 521-528. 
Chown, S.L. \& Klok, C.J. 2001. Habitat use, diet and body size of Heard Island weevils. Polar Biology 24, 706-712.

Chown, S.L., McGeoch, M.A. \& Marshall, D.J. 2002. Diversity and conservation of invertebrates on the sub-Antarctic Prince Edward Islands. African Entomology 10, 67-82.

Chown, S.L., Sinclair, B.J., Leinaas, H.P. \& Gaston, K.J. 2004. Hemispheric asymmetries in biodiversity - a serious matter for ecology. PLoS Biology 2, e406, 1701-1707.

Chown, S.L., Slabber, S., McGeoch, M.A., Janion, C. \& Leinaas, H.P. 2007. Phenotypic plasticity mediates climate change responses among invasive and indigenous arthropods. Proceedings of the Royal Society of London B 274, 2531-2537.

Chown, S.L. \& Smith, V.R. 1993. Climate change and the short-term impact of feral house mice at the sub-Antarctic Prince Edward Islands. Oecologia 96, 508-516.

Clarke, A. 2003. Evolution, adaptation and diversity: global ecology in an Antarctic context. In: Huiskes, A.H.L., Gieskes, W.W.C., Rozema, J., Schorno, R.M.L., Van der Vies, S.S. \& Wolff, W.J. (Ed.). Antarctic Biology in a Global Context. Backhuys Publishers, Leiden, pp.3-17.

Clarke, A., Barnes, D.K.A. \& Hodgson, D.A. 2005. How isolated is Antarctica? Trends in Ecology and Evolution 20, 1-3.

Clarke, A. \& Johnston, N.M. 2003. Antarctic marine benthic diversity. Oceanography and Marine Biology Annual Review 41, 47-114.
Cooper, J. \& Condy, P.R. 1988. Environmental conservation at the sub-Antarctic Prince Edward Islands: a review and recommendations. Environmental Conservation 15, 317-326.

Cooper, J. \& Headland, R.K. 1991. A history of South African involvement in Antarctica and at the Prince Edward Islands. South African Fournal of Antarctic Research 21, 77-91.

Cooper, J. \& Ryan, P.G. 2001. The agreement on the conservation of albatrosses and petrels: implications for research and monitoring at the Prince Edward Islands. South African Journal of Science 97, 78-79.

Crafford, J.E. 1990. The role of feral house mice in ecosystem functioning on Marion Island. In: Kerry, K.R. \& Hempel, G. (Eds.). Antarctic Ecosystems. Ecological Change and Conservation. Springer, Berlin, pp. 359-364.

Crafford, J.E. \& Chown, S.L. 1987. Plutella xylostella on Marion Island. Fournal of the Entomological Society of Southern Africa 50, 257-260.

Crafford, J.E., Scholtz, C.H. \& Chown, S.L. 1986. The insects of sub-Antarctic Marion and Prince Edward Islands; with a bibliography of entomology of the Kerguelen Biogeographical Province. South African Fournal of Antarctic Research 16, 42-84.

Crame, J.A. 1997. An evolutionary framework for the polar regions. fournal of Biogeography 24, 1-9.

Cuthbert, R. \& Hilton, G. 2004. Introduced house mice Mus musculus: a significant predator of threatened and endemic birds on Gough Island, South Atlantic Ocean? Biological Conservation 117, 483-489. 
Daehler, C.C. 2003. Performance comparisons of co-occurring native and alien invasive plants: Implications for conservation and restoration. Annual Review of Ecology, Evolution and Systematics 34, 183-211.

de Villiers, A.F. 1976. Littoral ecology of Marion and Prince Edward Islands (Southern Ocean). South African Fournal of Antarctic Research suppl. 1, 1-40.

Dingwall, P.R. 1987. Conserving the Natural Heritage of the Antarctic Realm. IUCN, Gland.

Dingwall, P.R. 1995. Progress in Conservation of the Subantarctic Islands. IUCN, Gland.

Domack, E., Duran, D., Leventer, A., Ishman, S., Doane, S., McCallum, S., et al. 2005. Stability of the Larsen B ice shelf on the Antarctic Peninsula during the Holocene epoch. Nature 436, 681-685.

Downes, M. 2002. First visitors to Heard Island. Anare Research Notes 104, 1-70.

Drake, J.M. \& Lodge, D.M. 2004. Global hot spots of biological invasions: evaluating options for ballast-water management. Proceedings of the Royal Society of London B 271, 575-580.

Dukes, J.S. \& Mooney, H.A. 1999. Does global change increase the success of biological invaders? Trends in Ecology and Evolution 14, 135-139.

Dunn, R.R. 2005. Modern insect extinctions, the neglected majority. Conservation Biology 19, 1030-1036.

Frenot, Y., Chown, S.L., Whinam, J., Selkirk, P.M., Convey, P., Skotnici, M., et al. 2005. Biological invasions in the Antarctic: extent, impacts and implications. Biological Reviews 80, 45-72.
Gaston, K.J., Jones, A.G., Hänel, C. \& Chown, S.L. 2003. Rates of species introduction to a remote oceanic island. Proceedings of the Royal Society of London B 270, 1091-1098.

Greenslade, P., Farrow, R.A. \& Smith, J.M.B. 1999. Long distance migration of insects to a subantarctic island. Fournal of Biogeography 26, 1161-1167.

Gremmen, N.J.M., Chown, S.L. \& Marshall, D.J. 1998. Impact of the introduced grass Agrostis stolonifera on vegetation and soil fauna communities at Marion Island, subAntarctic. Biological Conservation 85, 223-231.

Gremmen, N.J.M. \& Smith, V.R. 1999. New records of alien vascular plants from Marion and Prince Edward Islands, sub-Antarctic. Polar Biology 21, 401-409.

Gressitt, J.L. 1970. Subantarctic Entomology and Biogeography. Pacific Insects Monograph 23, 295-374.

Greve, M., Gremmen, N.J.M., Gaston, K.J. \& Chown, S.L. 2005. Nestedness of South Ocean island biotas: ecological perspectives on a biogeographical conundrum. Fournal of Biogeography 32, 155-168.

Grindley, J.R. \& Lane, S.B. 1979. Zooplankton around Marion and the Prince Edward Islands. Comité National Française des Recherches Antarctiques 44, 111-125.

Grosholz, E. 2002. Ecological and evolutionary consequences of coastal invasions. Trends in Ecology and Evolution 17, 22-27.

Grosholz, E.D. 2005. Recent biological invasion may hasten invasional meltdown by accelerating historical introductions. Proceedings of the National Academy of Sciences of the USA 102, 1088-1091. 
Hall, K. 2002. Review of Present and Quaternary periglacial processes and landforms of the maritime and subAntarctic region. South African fournal of Science 98, 71-81.

Hänel, C. \& Chown, S.L. 1999. Fifty years at Marion and Prince Edward Islands: A bibliography of scientific and popular literature. South African Fournal of Science 95, 87-112.

Headland, R.K. 1989. Chronological List of Antarctic Expeditions and Related Historical Events. Cambridge University Press, Cambridge.

Hill, J.K., Hughes, G.L., Dytham, G. \& Searle, J.B. 2006. Genetic diversity in butterflies: interactive effects of habitat fragmentation and climatedriven range expansion. Biology Letters 2, 152-154.

Hill, J.K., Thomas, C.D. \& Huntley, B. 1999. Climate and habitat availability determine 20th century changes in a butterfly's range margin. Proceedings of the Royal Society of London B 266, 1197-1206.

Huston, M.A. 2004. Management strategies for plant invasions: manipulating productivity, disturbance, and competition. Diversity and Distributions 10, 167-178.

Jones, A.G., Chown, S.L., Ryan, P.G., Gremmen, N.J.M. \& Gaston, K.J. 2003. A review of conservation threats on Gough Island: a case study for terrestrial conservation in the Southern Oceans. Biological Conservation 113, 75-87.

Kennedy, A.D. 1995. Antarctic terrestrial ecosystem response to global environmental change. Annual Review of Ecology and Systematics 26, 683-704.
King, J.C. \& Harangozo, S.A. 1998. Climate change in the western Antarctic Peninsula since 1945: observations and possible causes, Annals of Glaciology 27, 571-575.

Knox, G.A. 1994. The Biology of the Southern Ocean. Cambridge University Press, Cambridge.

Koh, L.P., Dunn, R.R., Sodhi, N.S., Colwell, R.K., Proctor, H.C. \& Smith, V.S. 2004. Species coextinctions and the biodiversity crisis. Science 305, 1632-1634.

Laws, R.M. (Ed.). 1984. Antarctic Ecology Volumes 1 and 2. Academic Press, London.

Lee, J.E. \& Chown, S.L. 2007. Mytilus on the move: transport of an invasive bivalve to the Antarctic. Marine Ecology Progress Series 339, 307-310.

LeMasurier, W.E. \& Thomson, J.W. 1990. Volcanoes of the Antarctic Plate and Southern Oceans. American Geophysical Union, Washington.

le Roux, P.G. \& McGeoch, M.A. 2007.

Changes in climatic extremes, variability and signatures on subAntarctic Marion Island. Climatic Change, in press. doi: 10.1007/ s10584-007-9259-y

Lewis, P.N., Bergstrom, D.M. \& Whinam, J. 2006. Barging in: a temperate marine community travels to the subantarctic. Biological Invasions 8, 787-795.

Lewis, P.N., Hewitt, C.L., Riddle, M. \& McMinn, A. 2003. Marine introductions in the Southern Ocean: an unrecognised hazard to biodiversity. Marine Pollution Bulletin 46, 213-223. 
Lombard, A.T., Reyers, B., Schonegevel, L.Y., Cooper, J., Smith-Adao, L.B., Nel, D.C. et al. 2007. Conserving pattern and process in the Southern Ocean: designing a marine protected area for the Prince Edward Islands. Antarctic Science 19, 39-54.

Longhurst, A. 1998. Ecological Geography of the Sea. Academic Press, London.

Lutjeharms, J.R.E. 1991. A history of recent South African marine research in the Southern Ocean. South African Journal of Antartic Research 21, 159-164.

Mack, R.N., Simberloff, D., Lonsdale, W.M., Evans, H., Clout, M. \& Bazzaz, F.A. 2000. Biotic invasions: causes, epidemiology, global consequences, and control. Ecological Applications 10, 689-710.

Marshall, D.J. \& Convey, P. 2004. Latitudinal variation in habitat specificity of ameronothroid mites (Oribatida). Experimental and Applied Acarology 34, 21-35.

Marshall, W.A. \& Chalmers, M.O. 1997. Airborne dispersal of Antarctic terrestrial algae and cyanobacteria. Ecography 20, 585-594.

McDougall, I., Verwoerd, W. \& Chevallier, L. 2001. K-Ar geochronology of Marion Island, Southern Ocean. Geological Magazine 138, 1-17.

McKinney, M.L. \& Lockwood, J. 1999. Biotic homogenization: a few winners replacing many losers in the next mass extinction. Trends in Ecology and Evolution 14, 450-453.

McQuaid, C.D. \& Froneman, P.W. 2004. Rhodes Southern Ocean Group: scientific findings from seventeen years of biological oceanography in the South African National Antarctic Programme. South African Fournal of Science 100, 571-577.
Mélice, J.-L., Lutjeharms, J.R.E., Rouault, M. \& Ansorge, I.J. 2003. Sea-surface temperatures at the subAntarctic islands Marion and Gough during the past 50 years. South African Fournal of Science 99, 363-366.

Millennium Ecosystem Assessment. 2005. Ecosystems and Human Well-being: Biodiversity Synthesis. World Resources Institute, Washington D.C.

Mooney, H.A. \& Hobbs, R.J. (Eds.). 2000. Invasive Species in a Changing World. Island Press, Washington D.C.

Muñoz, J., Felicísimo, A.M., Cabezas, F., Burgaz, A.R. \& Martínez, I. 2004. Wind as a long-distance dispersal vehicle in the Southern Hemisphere. Science 304, 1144-1147.

Naveen, R., Forrest, S.C., Dagit, R.G., Blight, L.K., Trivelpiece, W.Z. \& Trivelpiece, S.G. 2001. Zodiac landings by tourist ships in the Antarctic Peninsula region, 1989-99. Polar Record 37, 121-132.

Nel, D.C., Lutjeharms, J.R.E., Pakhomov, E.A., Ansorge, I.J., Ryan, P.G. \& Klages, N.T.W. 2001. Exploitation of mesoscale oceanographic features by grey-headed albatross Thalassarche chrysostoma in the southern Indian ocean. Marine Ecology Progress Series 217, 15-26.

Nel, D.C. \& Nel, J.L. 1999. Marine debris and fishing gear associated with seabirds at sub-Antarctic Marion Island, 1996/97 and 1997/98: in relation to longline fishing activity. CCAMLR Science $\mathbf{6}$, 85-96.

Nel, D.C., Nel, J.L., Ryan, P.G., Klages, N.T.W., Wilson, R.P. \& Robertson, G. 2000. Foraging ecology of grey-headed mollyhawks at Marion Island, southern Indian Ocean, in relation to longline fishing activity. Biological Conservation 96, 219-231. 
O’Dowd, D.J., Green, P.T. \& Lake, P.S. 2003. Invasional 'meltdown' on an oceanic island. Ecology Letters 6 , 812-817.

Olden, J.D., Poff, N.L., Douglas, M.R., Douglas, M.E. \& Fausch, K.D. 2004. Ecological and evolutionary consequences of biotic homogenization. Trends in Ecology and Evolution 19, 18-24.

Pakhomov, E.A. \& Chown, S.L. 2003. The Prince Edward Islands: Southern Ocean Oasis. Ocean Yearbook 17, 348-379.

Pakhomov, E.A. \& Froneman, P.W. 1999a. The Prince Edward Islands pelagic ecosystem: a review of achievements 1976-1990. Journal of Marine Systems 18, 297-310.

Pakhomov, E.A. \& Froneman, P.W. 1999b. Macroplankton/micronekton dynamics in the vicinity of the Prince Edward Islands (Southern Ocean): new concept for the biomass build up for higher trophic levels. Marine Biology 134, 501-515.

Parmesan, C. \& Yohe, G. 2003. A globally coherent fingerprint of climate change impacts across natural systems. Nature 421, 37-42.

Pauly, D., Christensen, V., Dalsgaard, J., Froese, R. \& Torres, F. 2005. Fishing down marine food webs. Science $\mathbf{2 7 9}$, 860-863.

Peck, L., Convey, P. \& Barnes, D.K.A. 2006. Environmental constraints on life histories in Antarctic ecosystems: tempos, timings and predictability. Biological Reviews 81, 75-109.

Pounds, J.A., Bustamante, M.R., Coloma, L.A., Consuegra, J.A., Fogden, M.P.L., Foster, P.N., et al. 2006. Widespread amphibian extinctions from epidemic disease driven by global warming. Nature $\mathbf{4 3 9}$, 161-167.
Richardson, D.M. \& Van Wilgen, B.W. 2004. Invasive alien plants in South Africa: how well do we understand the ecological impacts? South African Journal of Science 100, 45-52.

Root, T.L., Price, J.T., Hall, K.R., Schneider, S.H., Rosenzweig, C. \& Pounds, J.A. 2003. Fingerprints of global warming on wild animals and plants. Nature 421, 57-60.

Sanders, N.J., Gotelli, N.J., Heller, N.E. \& Gordon, D.M. 2003. Community disassembly by an invasive species. Proceedings of the National Academy of Sciences of the USA 100, 2474-2477.

Scott, L. 1985. Palynological indications of the Quaternary vegetation history of Marion Island (sub-Antarctic). Fournal of Biogeography 12, 413-431.

Scott, L. \& Hall, K.J. 1983. Palynological evidence for interglacial vegetation cover on Marion Island, subantarctic. Paleogeography, Paleoclimatology, Paleoecology 41, 35-43.

Slabber, S. \& Chown, S.L. 2002. The first record of a terrestrial crustacean, Porcellio scaber (Isopoda, Porcellionidae), from sub-Antarctic Marion Island. Polar Biology 25, 855-858.

Smith, V.R. 1977. A qualitative description of energy flow and nutrient cycling in the Marion Island terrestrial ecosystem. Polar Record 18, 361-370.

Smith, V.R. 1991. Terrestrial biological research at the Prince Edward Islands. South African Fournal of Antarctic Research 21, 118-123.

Smith, V.R. 2002. Climate change in the sub-Antarctic: An illustration from Marion Island. Climatic Change 52, 345-357.

Smith, V.R. \& Steenkamp, M. 1990. Climatic change and its ecological implications at a subantarctic island. Oecologia 85, 14-24. 
Stachowicz, J.J., Terwin, J.R., Whitlatch, R.B. \& Osman, R.W. 2002. Linking climate change and biological invasions: Ocean warming facilitates nonindigenous species invasions.

Proceedings of the National Academy of Sciences of the USA 99, 15497-15500.

Stanley, S.M. 1989. Earth and Life Through Time. W.H. Freeman, New York.

Van Zinderen Bakker, E.M., Winterbottom, J.M. \& Dyer, R.A. (Eds.). 1971. Marion and Prince Edward Islands. Report on the South African Biological and Geological Expedition 1965-1966. A.A. Balkema, Cape Town.

Walther, G.-R., Post, E., Convey, P., Menzel, A., Parmesan, C., Beebee, T.J.C., et al. 2002. Ecological responses to recent climate change. Nature 416, 389-395.
Watkins, B.P. \& Cooper, J. 1986.

Introduction, present status and control of alien species at the Prince Edward Islands, sub-Antarctic. South African Fournal of Antarctic Research 16, 86-94.

Watson, R.T. 2002. Climate Change 2001: Synthesis Report. Cambridge University Press, Cambridge.

Weimerskirch, H., Inchausti, P., Guinet, C. \& Barbraud, C. 2003. Trends in bird and seal populations as indicators of a system shift in the Southern Ocean. Antarctic Science 15, 249-256. 